\title{
Evaluation of Basmati Rice Varieties for Yield Performance and Economics under Farmers Field Situation in Muzaffarnagar District, India
}

\author{
R.C. Verma ${ }^{1}$, P.K. Singh ${ }^{2}$, Shripal $^{3}$, Shubham Arya ${ }^{4}$ and Vipin Kumar ${ }^{5 *}$ \\ ${ }^{1}$ SMS (Plant Protection), Krishi Vigyan Kendra, Muzaffarnagar, India \\ ${ }^{2}$ Krishi Vigyan Kendra, Muzaffarnagar, India \\ ${ }^{3}$ SMS (Plant Breeding), Krishi Vigyan Kendra, Muzaffarnagar, India \\ ${ }^{4}$ SRF (Agronomy), ICAR-Central Institute of Research on Cattle, Meerut, India \\ ${ }^{5}$ S.V.P. University of Agriculture \& Technology, Meerut, UP- 250110, India \\ *Corresponding author
}

\begin{tabular}{|c|c|}
\hline & A B S T R A C T \\
\hline \multicolumn{2}{|l|}{ Keywords } \\
\hline $\begin{array}{l}\text { Pusa Basmati } \\
\text { varieties, Yield } \\
\text { assessment, } \\
\text { Performance, CB } \\
\text { Ratio. }\end{array}$ & \multirow{3}{*}{$\begin{array}{l}\text { The KVK conducted On Farm Trials and Frontline Demonstrations to test } \\
\text { the adaptability of Basmati varieties under farmers' field condition. The } \\
\text { varieties tested were Pusa Basmati-1121, Pusa Basmati-1509, Pusa } \\
\text { Basmati-1612 and Pusa Basmati-1 as check. The results indicated that yield } \\
\text { increase of Basmati varieties ranged between } 7.95 \text { to } 26.75 \text { percent over } \\
\text { farmers practice. The variety Pusa Basmati-1612 gave highest yield of } \\
52.60 \mathrm{qt} / \text { ha with net return of Rs } 105625.00 \text { and CB ratio of 1:5.08. }\end{array}$} \\
\hline Article Info & \\
\hline $\begin{array}{l}\text { Accepted: } \\
\text { 12 October } 2017 \\
\text { Available Online: } \\
\text { 10 December } 2017\end{array}$ & \\
\hline
\end{tabular}

\section{Introduction}

In district Muzaffarnagar rice is cultivated on 22302 ha area with average $25.07 \mathrm{qt} / \mathrm{ha}$ productivity. The basmati rice is known for its typical fragrance when cooked. They also fetch a premium price in the local and regional market, besides having considerable export potential. The basmati is promising foreign exchange earner (Singh et al., 1997). The fine grain, soft texture and extra elongation with least breadth-wise swelling on cooking endow 'Basmati' rice a special place in domestic and international market (Siddiqi, 1990). Basmati rice of Indian subcontinent is high priced in international market for its unique quality.

The traditional basmati varieties are tall, prone to lodging, diseases, photoperiod and temperature sensitive and very low yielding.

In present study the basmati varieties namely Pusa Basmati-1509, Pusa Basmati-1612, Pusa Basmati-1121 and Pusa Basmati-1 (Farmers Practice) were selected for assessment and performance, as these varieties are high yielding and semi dwarf in nature. 


\section{Materials and Methods}

The trial and demonstration were conducted at farmers' field during Kharif-2015 and 2016. Four basmati varieties alongwith farmers practice, namely Pusa Basmati-1509, Pusa Basmati-1612, Pusa Basmati-1121 and Pusa Basmati-1(Farmers Practice) were used for analysis, the seed yield and net returns data of the varieties were analysed.

For the estimation of technology gap, extension gap and technology index, the formulae were used as per method of Samui et al., (2000) and Sagar and Chandra (2004)

Technology Gap = Potential Yield Demonstration Yield

Extension Gap $=$ Demonstration yieldFarmers Yield

Technology Index = Potential YieldDemonstration Yield/Potential yieldX100

\section{Results and Discussion}

The potential, productivity and economics of the basmati varieties along with local check were evaluated and data are given in Table 1 and 2 .

From the data presented in Table 1 it is quite clear that the percent increase in the yield over local check was $16.50,26.75$, and 7.95 for Pusa Basmati-1509, Pusa Basmati-1612 and Pusa Basmati-1121, respectively.

The seed yield increased significantly in the range of 44.80 to $52.60 \mathrm{qt} / \mathrm{ha}$ in basmati varieties as compared to farmers practice (41.50 qt/ha).

This indicated that field demonstrations are quite successful in bridging up yield gap between improved and farmers practices
(Rana et al., 2002). Singh and Rana (2006) reported seed yield increase up to $20.70 \mathrm{qt} / \mathrm{ha}$ by Pusa Barani variety of mustard crop. Biswas et al., (1998) also reported varietal differences of grain yield in scented rice. Kusutani et al., (2000) and Dutta et al., (2002) reported that the genotypes which produced higher number of grains per panicle also showed higher grain yield in rice.

The economics of demonstrations shown in Table 2, indicated that the additional return of basmati varieties over farmers practice, ranged from Rs. 8480.00 to 27520.00 Rs./ha. It was high in Pusa Basmati-1612 (Rs. 27520.00). The gross return of basmati varieties ranged between Rs. 112000.00 to 131500.00 rs./ha and net return Rs. 86585.00 to $105625.00 \mathrm{Rs}$./ha also. The highest net return of Rs.105625.00/ha of basmati variety Pusa basmati-1612 was in line with the finding of Singh and Rana (2006), who reported about $13149.00 \mathrm{Rs} / \mathrm{ha}$ of net return in mustard crop.

The cost benefit ratio (Table 2), of basmati variety Pusa Basmati-1612 ranked first (1:5.08) followed by Pusa Basmati-1509 (1:4.74) and Pusa Basmati-1121 (1:1.41). Hedge (2006) reported that mustard crop by nature is hardy and mostly grown under rainfed condition can impart stability of production system under harsh condition.

Technology gap (Table 1) ranged from 5.2 to $7.40 \mathrm{qt} / \mathrm{ha}$, with an overall mean difference $6.41 \mathrm{qt} / \mathrm{ha}$. This gap is minimum in Pusa Basmati-1121(5.2) and maximum in Pusa Basmati-1612(7.40) noticed under study.

The yield gap between potential and frontline demonstrations was due to climatic, edaphic, socioeconomic and management practices. Kadian et al., (1997) reported that technology gap can be narrowed down only by location specific technology based recommendations. 
Table.1 Productivity, yield gap and extension gap of basmati varieties

\begin{tabular}{|c|c|c|c|c|c|c|c|c|c|}
\hline \multirow[t]{2}{*}{ Varieties } & \multirow{2}{*}{$\begin{array}{c}\text { No. of } \\
\text { Demonstration }\end{array}$} & \multirow{2}{*}{$\begin{array}{l}\text { Duration of } \\
\text { Study (Years) } \\
2015 \& 2016\end{array}$} & \multicolumn{3}{|c|}{ Avg. Yield (Qt/ha) } & \multirow{2}{*}{$\begin{array}{l}\text { \% Increased } \\
\text { Yield }\end{array}$} & \multirow{2}{*}{$\begin{array}{l}\text { Technology } \\
\operatorname{gap}(q \mathrm{t} / \mathrm{ha})\end{array}$} & \multirow{2}{*}{$\begin{array}{l}\text { Extension gap } \\
\text { (qt/ha) }\end{array}$} & \multirow{2}{*}{$\begin{array}{l}\text { Technological } \\
\text { Index }(\%)\end{array}$} \\
\hline & & & $\mathbf{P}$ & IP & FP & & & & \\
\hline PB-1509 & 15 & 02 & 55 & 48.35 & 41.50 & 16.50 & 6.65 & 6.85 & 12.09 \\
\hline PB-1612 & 15 & 02 & 60 & 52.60 & 41.50 & 26.75 & 7.40 & 11.1 & 12.33 \\
\hline PB-1121 & 15 & 02 & 50 & 44.80 & 41.50 & 7.95 & 5.2 & 3.3 & 10.4 \\
\hline Mean & & & & 48.58 & 41.50 & 17.06 & 6.41 & 7.08 & 11.60 \\
\hline
\end{tabular}

$\mathrm{P}=$ Potential Yield, $\mathrm{IP}=$ Improved Practice, $\mathrm{FP}=$ Farmers Practice

Table.2 Economics of basmati rice varieties

\begin{tabular}{|c|c|c|c|c|c|c|c|}
\hline Varieties & $\begin{array}{l}\text { Grain } \\
\text { Yield(qt/ha) }\end{array}$ & $\begin{array}{l}\text { Cost of } \\
\text { Cultivation(Rs/ha) }\end{array}$ & $\begin{array}{l}\text { Gross } \\
\text { Return(Rs/ha) }\end{array}$ & $\begin{array}{l}\text { Net } \\
\text { Return(Rs/ha) }\end{array}$ & CB Ratio & $\begin{array}{l}\text { Additional } \\
\text { Yield over } \\
\text { check }\end{array}$ & $\begin{array}{l}\text { Additional } \\
\text { Net Return } \\
\text { over check }\end{array}$ \\
\hline PB-1509 & 48.35 & 25500.00 & 120875.00 & 95375.00 & $1: 4.74$ & 16.50 & 17270.00 \\
\hline PB-1612 & 52.60 & 25875.00 & 131500.00 & 105625.00 & $1: 5.08$ & 26.75 & 27520.00 \\
\hline PB-1121 & 44.80 & 25415.00 & 112000.00 & 86585.00 & $1: 4.41$ & 7.95 & 8480.00 \\
\hline Mean & 48.58 & 25596.66 & 121458.33 & 95861.66 & $1: 4.74$ & 17.06 & 17756.66 \\
\hline Check & 41.50 & 25645.00 & 103750.00 & 78105.00 & $1: 4.04$ & - & - \\
\hline
\end{tabular}


Table 1 showed that the extension gap ranged from 3.3 to $11.1 \mathrm{qt} / \mathrm{ha}$, with an overall mean difference $7.08 \mathrm{qt} / \mathrm{ha}$. High extension gap (11.1 qt/ha) was recorded from variety Pusa Basmati-1612, followed by Pusa Basmati1509(6.65) and Pusa Basmati-1121(3.3) qt/ha. This indicated there is need to educate the farmers through various extension tools. These results are also in confirmation with those of Gupta and Sharma (2005).

There was clear cut and significant yield gap between farmers practice and demonstration field. The choice of basmati variety is also an important factor leading to additional net return. The extension and technology gap can be bridged by sustained effort of extension agencies and by adopting location specific technologies.

\section{References}

Rana, V.S.; Malik, A.C. and Midha, L.K., (2002). Evaluating gap in transfer of dry land technology in mustard frontline demonstrations in Haryana. $J$. Agron., 18(1\&2): 1148-1149.

Singh, T. and Rana, K.S., (2006). Effect of moisture conservation and fertility on Indian mustard(Brassica juncea) and Lentil(Lens culinaris) intercropping system in rainfed condition. Ind. J. Agron., 51(4):267-270.

Kadian, K.S., Sharma, R. and Sharma, A.K.,(1997). Evaluation of frontline demonstration trial on oilseed in Kangra Vally of H.P. Annals of Agril. Res. 18(10): 40-43.
Hedge, D.M., (2006). Oilseed crop diversification In: Extended summaries of National Symposium on Conservation agricultural and environment. Oct. 26-28, 2006 held at BHU, Varanasi.

Samui, S.K., Maitra, S., Roy, K., Mondal, A.K. and Saha, D., (2000). Evaluation of frontline demonstrations on groundnut (Arachis hypogea L). J. of Indian Society of Coastal Agriculture Research. 18(2): 180-183.

Sagar, R.L. and Chandra, G.(2004). Evaluation on frontline demonstration on mustard in Sundarbans, W.B. Indian Journal of Extension Education. 40(3\&4): 96-97.

Biswas, J.K., Hossain, M.A., sarkar, B.C., Hassan, M and Haque, M.Z., (1998). Yield performance of several rice varieties seeded directly as late aman crops. Bangladesh J. of Life Sci., 10:47-52.

Kusutani, A., Tovata, M., Asanuma, K., and Kui, J., (2000). Studies on the varietal differences of harvest index and morphological characteristics of rice. Japanese J. Crop Sci., 69:359-364.

Singh, K.K., and Singh, P.K., (2012). Evaluation of Basmati rice varieties for yield assessment and economics under farmers field conditions. New Agriculturist, 23(1):11-14.

Singh, K.K., Singh, P.K. and Ashok., (2011). Analysis of yield, performance and adoption of Basmati rice variety PB1401 in Saharanpur district. New Agriculturist. 22(1,2): 1-3.

\section{How to cite this article:}

Verma, R.C., P.K. Singh, Shripal, Shubham Arya and Vipin Kumar. 2017. Evaluation of Basmati Rice Varieties for Yield Performance and Economics under Farmers Field Situation in Muzaffarnagar District. Int.J.Curr.Microbiol.App.Sci. 6(12): 1552-1555. doi: https://doi.org/10.20546/ijcmas.2017.612.173 